\title{
Late Cretaceous and Cenozoic Geology of the New Madrid Seismic Zone
}

\author{
by Roy B. Van Arsdale and Robin K. TenBrink
}

\begin{abstract}
Structure-contour maps constructed from well, seismic reflection, and outcrop data of the tops of the Paleozoic section, Upper Cretaceous section, Paleocene Midway Group, and Eocene section illustrate the post-Paleozoic structure of the New Madrid seismic zone region. Isopach maps of the Late Cretaceous section, Midway Group, and Eocene section help constrain the timing of the structural events. These maps, which encompass much of the northern Mississippi embayment, reveal reactivation of the underlying late Precambrian/Cambrian Reelfoot rift during Midway Group deposition but no reactivation during Late Cretaceous or Eocene deposition. The structure-contour maps also indicate a subtle, south-plunging depression on the tops of the Paleozoic, Upper Cretaceous, and Midway Group along the axis of the northern Mississippi embayment that we have called a trench. This trench is 50-km wide, has a maximum depth of $100 \mathrm{~m}$, and appears to have formed during the Eocene. The trench's western boundary coincides with the Blytheville arch/Lake County uplift and its southeastern margin underlies Memphis, Tennessee. The Blytheville arch/Lake County uplift is the structure responsible for the New Madrid seismic zone, and thus it is possible that the southeastern margin of the trench is also a fault zone.

Northern Mississippi embayment post-Paleozoic stratigraphy consists of sands, silts, and clays that thicken from $477 \mathrm{~m}$ at New Madrid, Missouri, to $987 \mathrm{~m}$ near Memphis, Tennessee. The uniformity of these sediments indicates their elastic properties and therefore seismic velocities are very similar; however, variations in cementation and unconformities within the section may influence seismic-wave propagation.
\end{abstract}

\section{Introduction}

Earthquakes of the New Madrid seismic zone occur within Precambrian and lower Paleozoic strata at depths between 4 and $12 \mathrm{~km}$ beneath the northern portion of the Mississippi embayment (Fig. 1). The Mississippi embayment is a southwest plunging trough of late Cretaceous and Tertiary age (Stearns, 1957; Pryor, 1960). Formation of the Mississippi embayment has been attributed to the opening of the Gulf of Mexico and reactivation of the underlying late Precambrian to Cambrian Reelfoot rift (Burke and Dewey, 1973; Ervin and McGinnis, 1975; Kane et al., 1981; Braile et al., 1982). However, Cox and Van Arsdale (1997) argue that the Mississippi embayment formed as a consequence of plate tectonic drifting of the Mississippi Valley over the Bermuda hotspot in the Late Cretaceous. During early Late Cretaceous the Bermuda hotspot thermally lifted the central and southern Mississippi River Valley region and formed a north-trending arch from which a minimum of $2 \mathrm{~km}$ of $\mathrm{Pa}-$ leozoic strata were eroded (Cox and Van Arsdale, 1997). When the North American plate drifted west, off of the hotspot during the middle Late Cretaceous, the denuded Mis- sissippi Valley region cooled and subsided to form the Mississippi embayment trough. As a consequence of the subsidence, the Mississippi embayment is filled with $987 \mathrm{~m}$ of Late Cretaceous and Cenozoic sediments along its axis at Memphis, Tennessee.

Numerous articles have addressed the Late Cretaceous and Cenozoic geology of the northern Mississippi embayment (NME) (Fisk, 1944; Caplan, 1954; Stearns, 1957; Pryor, 1960; Murray, 1961; Stearns and Marcher, 1962; Marcher and Stearns, 1962; Boswell et al., 1965; Petersen et al., 1985; Brahana and Mesko, 1988; Galloway et al., 1991; Sharp et al., 1991; Sohl et al., 1991; Hosman, 1996). In this article we summarize the Late Cretaceous and Cenozoic geology of the NME and present new structure-contour and isopach maps of a portion of the NME centered on the New Madrid seismic zone. These data contribute to our understanding of the structure of the NME and also provide thicknesses, distributions, and compositions of the Late Cretaceous and Cenozoic embayment sediments that will affect seismic-wave propagation and ground motion in the event 


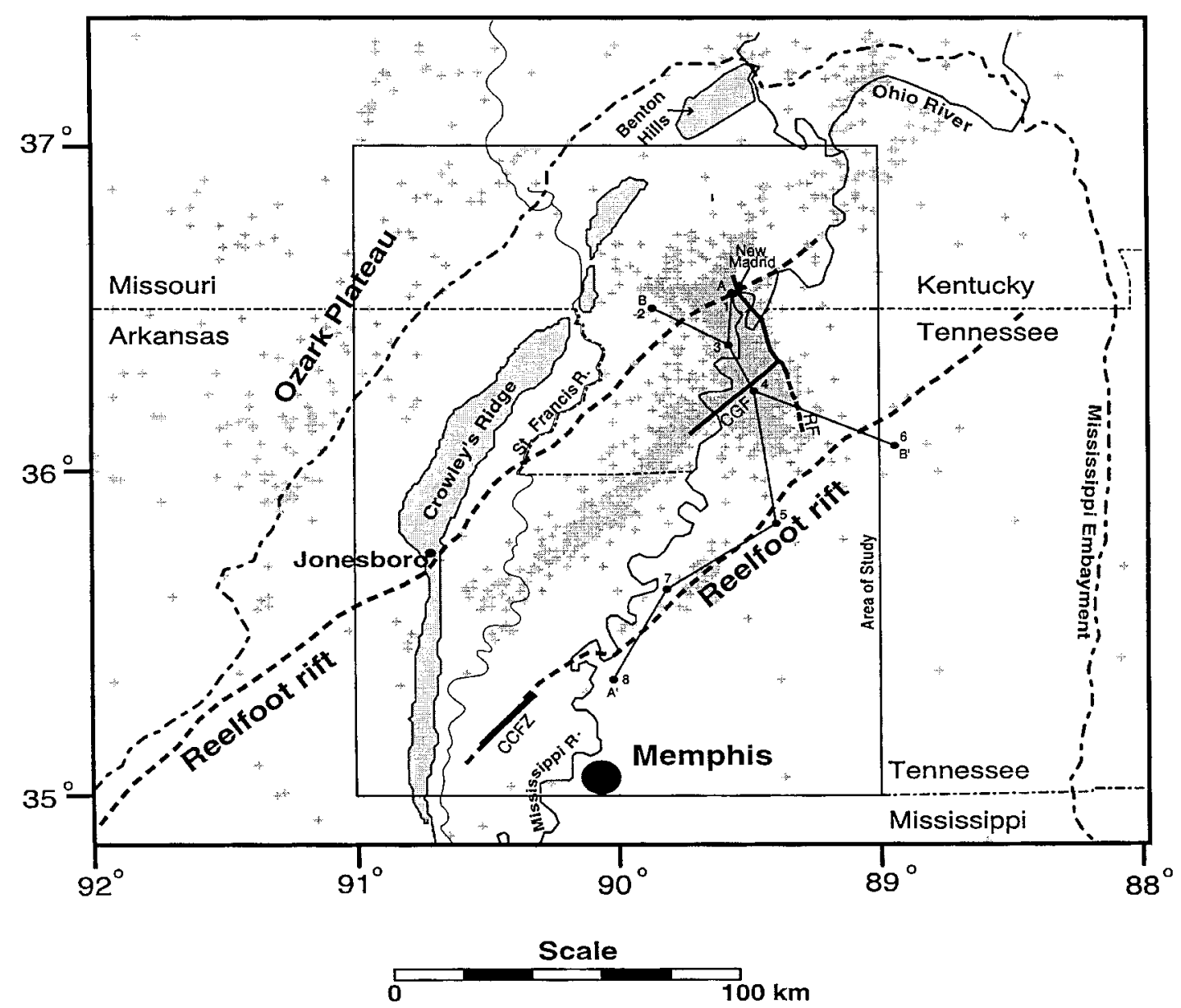

Figure 1. Major physiographic and structural features of the northern Mississippi embayment. Cross-sections $A-A^{\prime}$ and $B-B^{\prime}$ are illustrated in Figure 8. Crosses locate microearthquakes that define the New Madrid seismic zone. The interior box is the area covered in Figure 3-7. CCFZ, Crittenden County fault zone; CGF, Cottonwood Grove fault; RF, Reelfoot fault.

of a large New Madrid earthquake. We hope these data will provide a geologic framework for future seismologic and engineering studies within the New Madrid seismic zone.

\section{Construction of Structure-Contour and Isopach Maps}

Well $\log$, seismic reflection, and outcrop data were collected within a $2^{\circ}$ by $2^{\circ}$ block (Fig. 1) centered on the New Madrid seismic zone for the elevations of the tops of the Paleozoic section, Late Cretaceous section, early to late Paleocene Midway Group, and the late Paleocene through early Oligocene section (Fig. 2) (see Mihills, 1998, for data sources and procedures). The late Paleocene through early Oligocene section consists of the Wilcox Group, Claiborne Group, and Jackson Formation. For the sake of brevity, we herein refer to the Wilcox Group through Jackson Formation as the Eocene section. Well and outcrop data, and elevations calculated from the seismic reflection data (Mihills, 1998) were combined into one data set for each stratigraphic top; structure-contour maps were constructed using the mapping software Surfer for Windows 6.0 by Golden Software, Inc. (Figs. 3-6). Interval velocities used in the conversion of time to depth in the seismic reflection lines were: $1821 \mathrm{~m} / \mathrm{sec}$ for the interval from the top of the Midway Group to the ground surface, $1940 \mathrm{~m} / \mathrm{sec}$ for the interval from the top of the Cretaceous to the top of the Midway Group, and $2000 \mathrm{~m} / \mathrm{sec}$ for the interval from the top of the Paleozoic to the top of the Cretaceous. The Delaunay Triangulation with linear interpolation gridding algorithm was used in the contouring (Keckler, 1995). Triangulation with linear interpolation was selected because it is an exact interpolator (data points coinciding with grid nodes are honored exactly), and because this method can preserve breaks in lines (faults) where data density on both sides of the fault is fairly high (Keckler, 1995). Isopach maps (Fig. 7) of the Late Cretaceous section, the Midway Group, and the Eocene section were created by subtracting respective elevation grid files and then contouring the resultant grid files using Delaunay Triangulation. 


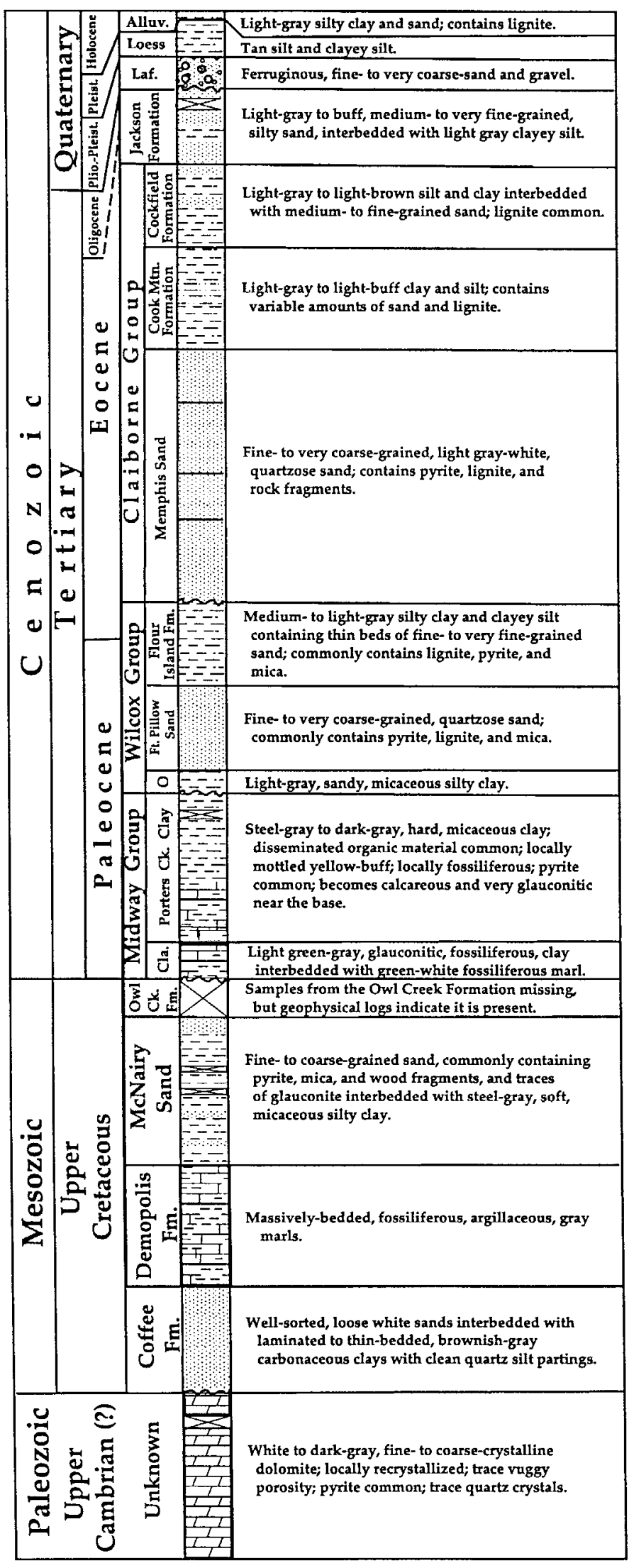

Legend

Major intervals with no samples

\%? Sand and Gravel

Sand

$=:=$ Silt

$E=-$ Clay

Calcareous Clay

Dolomite

$\sim$ Unconformity

Alluv $=$ Alluvium

Laf. = Lafayette $\mathrm{Fm}$.

$\mathrm{O}=$ Old Breastworks Fm.

$\mathrm{Cla},=$ Clayton Fm.

Figure 2. Geologic column for the New Mardrid seismic zone (modified from Crone, 1981). 


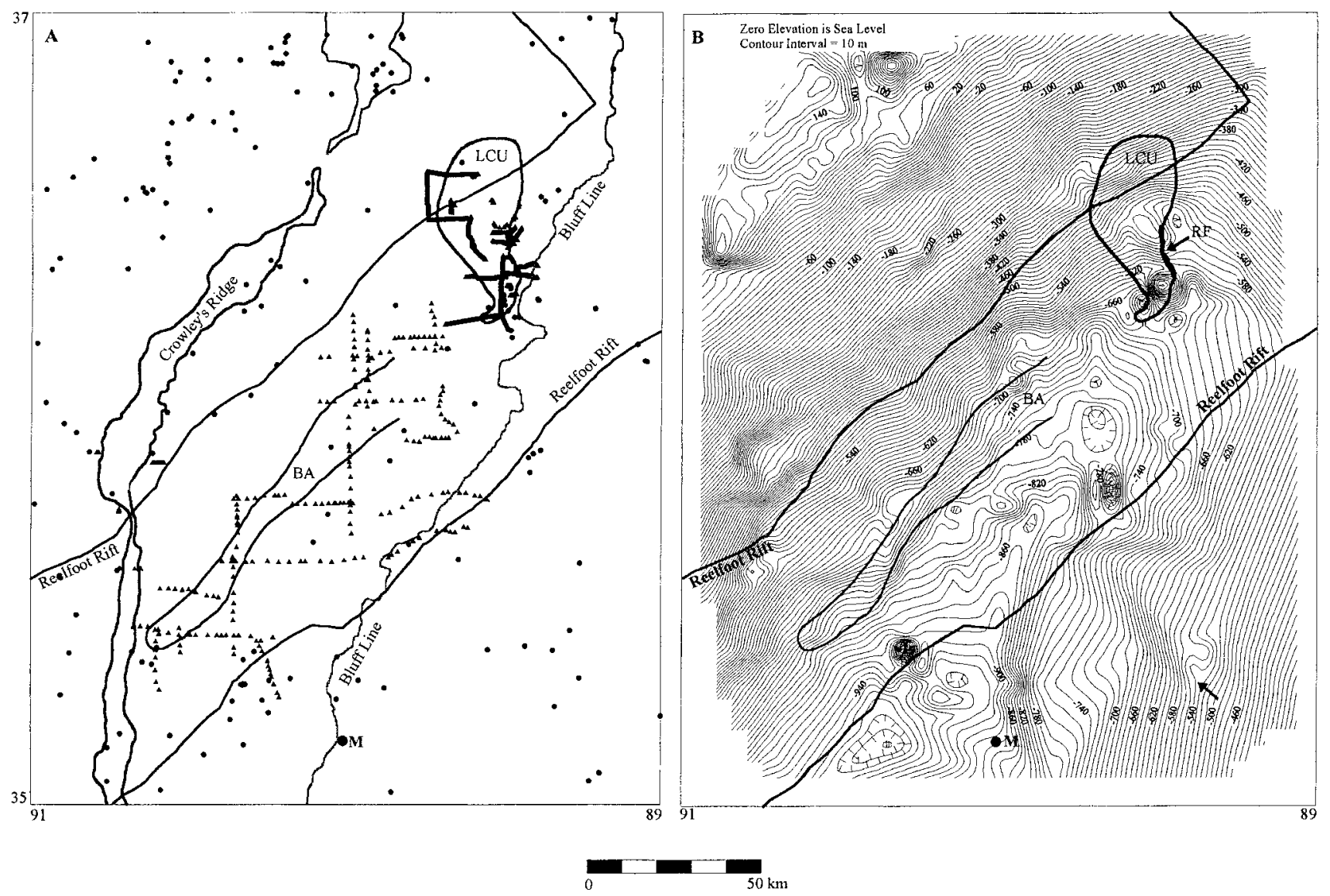

Figure 3. Data (a) and structure contour map (b) of the top of the Paleozoic strata. See Figure 1 for location within the Mississippi embayment. In (a) the dots represent wells, triangles are depths determined from seismic reflection lines, and the solid lines are depths determined from closely spaced reflection line data. M, Memphis; LCU, Lake County uplift; BA, Blytheville arch. Arrow indicates flexure in contour lines that may be a fault.

\section{Post-Paleozoic Stratigraphy of the Northern Mississippi Embayment}

The modern Gulf Coast region is an analog for Late Cretaceous and Cenozoic sedimentation in the Mississippi embayment. Physiographically the modern Mississippi embayment and northern Gulf Coast are broadly divided into the Mississippi River flood plain, the Mississippi River delta plain, coastal shoreline east and west of the Mississippi River, near-shore marine, and deep marine. Each of these environments is dominated by particular sediments. These same types of sediments occur in the Late Cretaceous and Tertiary section of the Mississippi embayment. As sea level rose and fell during the Late Cretaceous and Tertiary the shoreline of the Gulf of Mexico, and all of its associated depositional environments, migrated north and south, respectively, into the NME. Thus, the lateral and vertical distribution of these Late Cretaceous and Tertiary depositional environments and their associated sediment types is complex.

In the following discussion we summarize the Late Cre- taceous through Cenozoic stratigraphy of the northern Mississippi embayment (Figs. 1, 2, and 8) (Crone, 1981). The north-south cross-section line (A-A' in Figs. 1 and 8 ) is discussed in detail because it trends down the axis of the NME and because it illustrates the post-Paleozoic stratigraphy from the central portion of the New Madrid seismic zone to near Memphis, in Shelby County, Tennessee. Stratigraphy of the east-west cross-section is essentially the same as the north-south cross-section (Fig. 8).

\section{Late Cretaceous Depositional History}

Upper Cretaceous sediments unconformably overlie lower Paleozoic strata as old as Cambrian Knox Group in the NME (Stearns and Marcher, 1962; Cox and Van Arsdale, 1997). The Late Cretaceous sea transgressed from southeast to northwest, therefore, the basal Cretaceous sediments are older at the southern margin of the NME (Fig. 8). In Shelby County, Tennessee, the Coffee Formation overlies the Paleozoic unconformity (Fig. 2) (Crone, 1981). The Coffee Formation is a well-sorted, loose-to-friable sand that is in- 


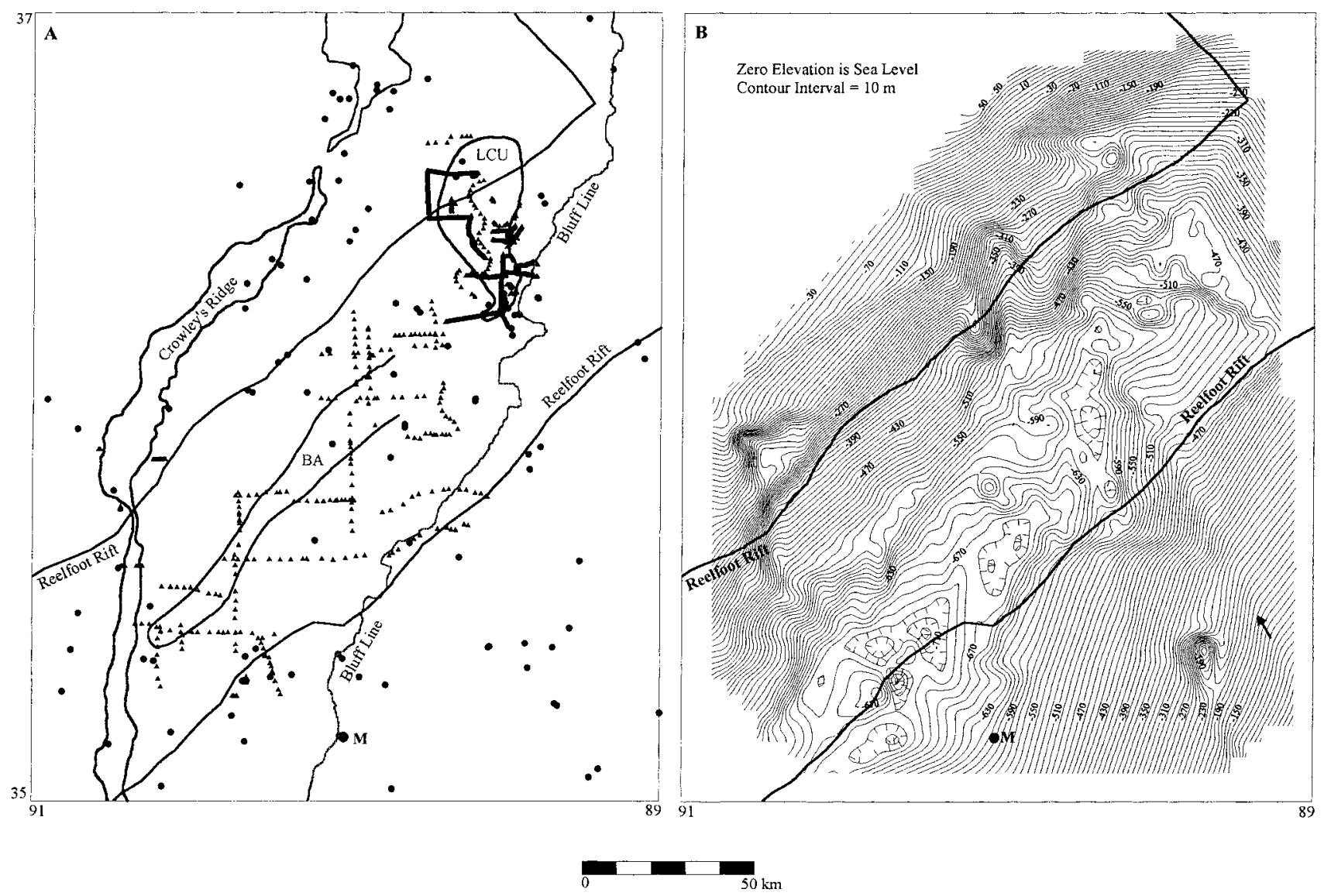

Figure 4. Data (a) and structure contour map (b) of the top of the Upper Cretaceous strata. See Figure 1 for location within the Mississippi embayment. In (a) the dots represent wells, triangles are depths determined from seismic reflection lines, and the solid lines are depths determined from closely spaced reflection line data. M, Memphis; LCU, Lake County uplift; BA, Blytheville arch. Arrow indicates flexure in contour lines that may be a fault.

terbedded with thin carbonaceous clays (Russell et al., 1982). This formation is approximately $32-\mathrm{m}$ thick beneath Shelby County but thins northward and is not present in the New Madrid test well (see Fig. 1, well \#3) (Crone, 1981; Frederiksen et al., 1982). Overlying the Coffee Formation in the southern part of the cross-section is the Demopolis Formation (Moore and Brown, 1969). The Demopolis Formation is a calcareous marine clay that thins northward. Beneath Shelby County the clay is $140-\mathrm{m}$ thick, but it is not present in the New Madrid test well. Overlying the Demopolis Formation is the McNairy Sand. This unit is a 130-mthick calcareous marine sand beneath Shelby County, but it grades to a fluvial/deltaic sand northward, where it thins to 95 m beneath New Madrid.

\section{Paleocene-Miocene Depositional History}

An unconformity separates the Late Cretaceous McNairy Sand and overlying Paleocene Midway Group. This unconformity marks the Late Cretaceous regression, subaerial exposure of the Late Cretaceous sediments, and Paleo- cene transgression of the Mississippi embayment sea. The Midway Group is a marine clay that thins from $160 \mathrm{~m}$ in Shelby County to $100 \mathrm{~m}$ beneath New Madrid. Unconformably overlying the Midway Group is the Paleocene to Eocene Wilcox Group. In ascending order, the Wilcox is subdivided into the Old Breastworks Formation, the Fort Pillow Sand, and the Flour Island Formation. The Old Breastworks Formation is a 95-m-thick clayey silt beneath Shelby County (Hosman, 1966) that grades to a silty clay in the New Madrid test well (Frederiksen et al., 1982) and pinches out northward beneath the town of New Madrid. The Fort Pillow Sand is a 64-m-thick marine sand at Shelby County that thins and grades to a fluvial/deltaic sand northward, where it is $32-\mathrm{m}$ thick beneath New Madrid. Overlying the Fort Pillow Sand is the Flour Island Formation, which consists of alternating beds of silt, clay, and sand. This unit also is more terrestrial from south to north and thins northward from $80 \mathrm{~m}$ to $31 \mathrm{~m}$. An unconformity marks the top of the Wilcox Group. The overlying middle Eocene Claiborne Group marks a marine transgression and is subdivided in ascending order into the 


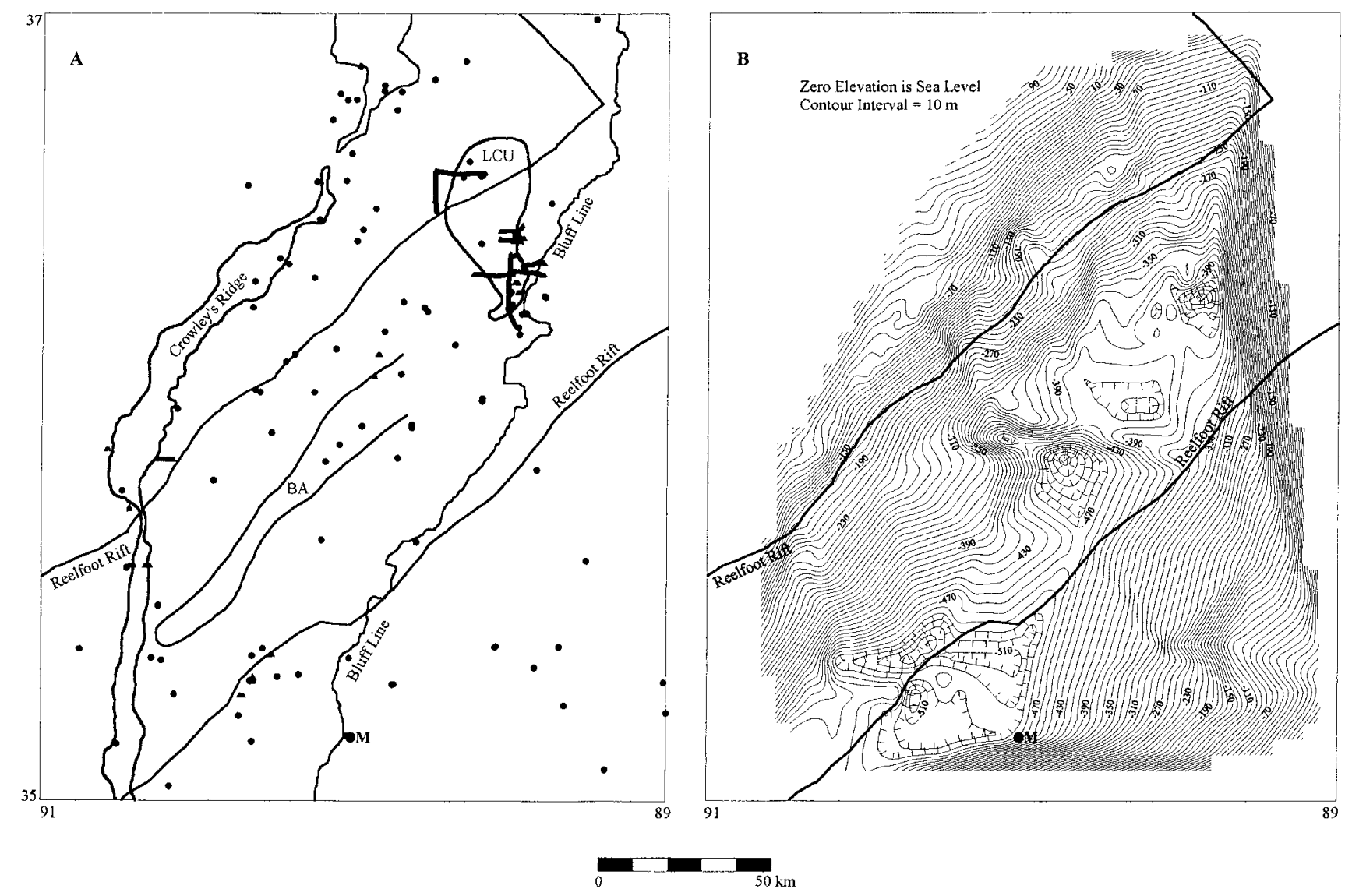

Figure 5. Data (a) and structure contour map (b) of the top of the Paleocene Midway Group. See Figure 1 for location within the Mississippi embayment. In (a) the dots represent wells and the solid lines are depths determined from closely spaced reflection line data. M, Memphis; LCU, Lake County uplift; BA, Blytheville arch.

Memphis Sand, the Cook Mountain Formation, and the Cockfield Formation. In this cross-section (Fig. 8), however, the Cook Mountain and Cockfield formations are combined and labeled as Cook Mountain Formation. The Memphis Sand is a fluvial/deltaic sand that is $223-\mathrm{m}$ thick beneath Shelby County and thins northward to 110-m thick beneath New Madrid. The overlying Cook Mountain Formation is a clay and silt fluvial/deltaic unit with minor sand lenses and lignite beds (Frederiksen et al., 1982). Cockfield Formation sediments consist of fluvial/deltaic silt and clay interbedded with sand and lignite beds. The combined thickness of the Cook Mountain and Cockfield formations is $64 \mathrm{~m}$ in Shelby County, thinning to $30 \mathrm{~m}$ in Lauderdale County, Tennessee (well \#5 of Fig. 8), and thickening to $48 \mathrm{~m}$ beneath New Madrid. The Eocene to Oligocene Jackson Formation (Nelson, 1998) is a fluvial/deltaic silty sand interbedded with clayey silt and lignite that is $16 \mathrm{~m}$ thick in Shelby County and 41-m thick beneath New Madrid. Jackson Formation thickness is quite variable because its upper contact is an unconformity overlain by Quaternary Mississippi River alluvium within the valley and by Pliocene-Pleistocene Lafayette Formation (Upland Gravel) on the bluffs east of the
Mississippi River (Autin et al., 1991). With the exception of Miocene gravels (Olive, 1980; Harrison and Schultz, 1994), there are no Oligocene or Miocene sediments above the Jackson Formation in the NME. Thus, it appears that the NME has been above sea level since Oligocene Jackson Formation time.

\section{Pliocene-Quaternary Depositional History}

The surface and near-surface stratigraphy is different east and west of the Mississippi River in the NME and changes along the line of section between the \#1 J. E. Vaughan and \#1 T. A. Lee wells (Fig. 8). West of the Mississippi Valley bluff line, the surface stratigraphy consists of Mississippi River Pleistocene (terraces) and Holocene alluvium. East of the bluff line the near-surface stratigraphy consists of the Lafayette Formation (Upland Gravel) and the overlying Pleistocene loess.

The Mississippi River sediments, which are approximately 50-m thick, consist of a basal sandy gravel overlain by sands and capped by silts and clays (Saucier, 1994). These flood plain sediments are below the Lafayette Formation and inset $64 \mathrm{~m}$ into the Jackson Formation. Thus, 


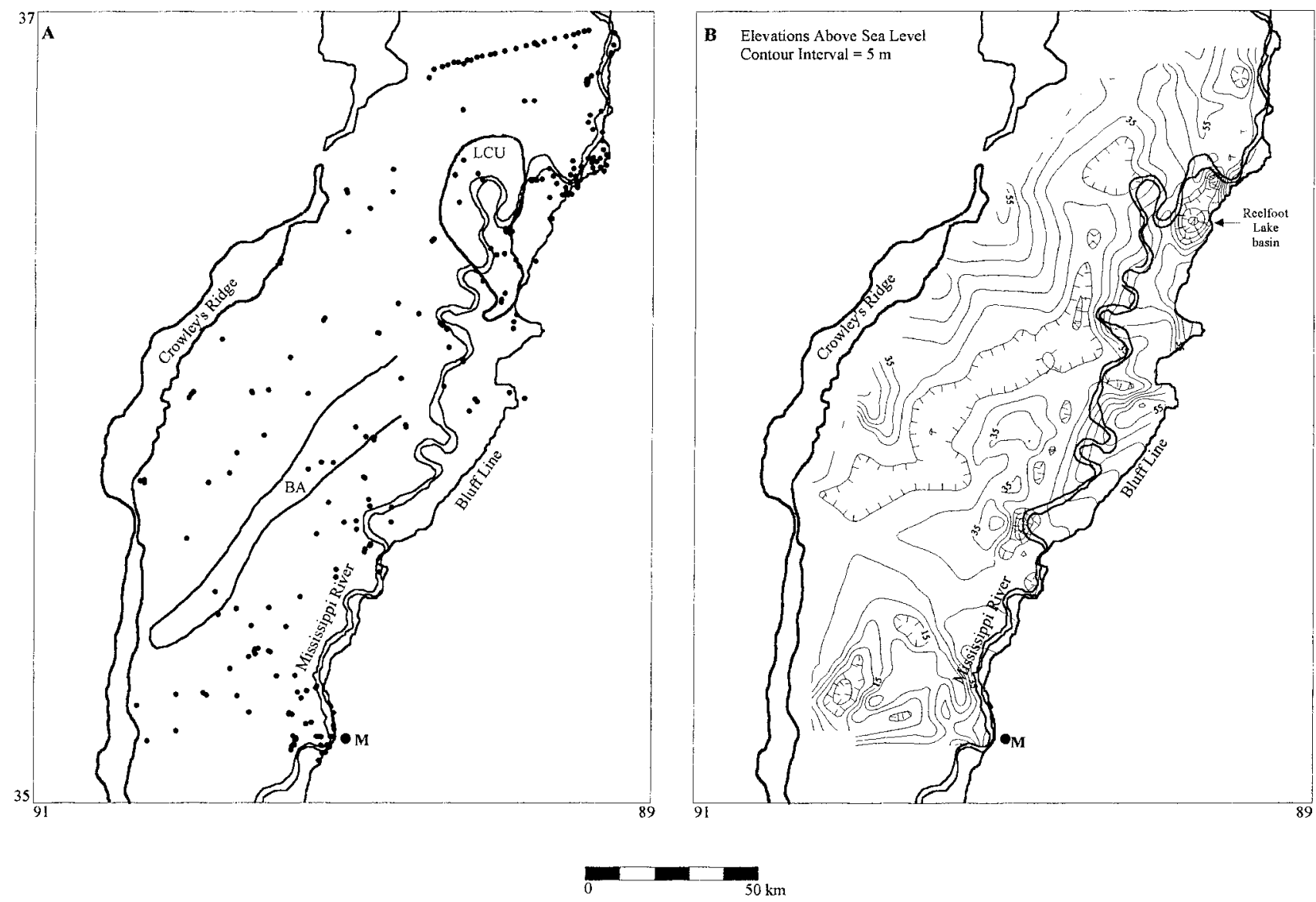

Figure 6. Data (a) and structure contour map (b) of the top of the Eocene strata. See Figure 1 for location within the Mississippi embayment. The dots in (a) represent wells. M, Memphis; LCU, Lake County uplift; BA, Blytheville arch.

approximately $14 \mathrm{~m}$ of Jackson Formation is exposed in the base of the Mississippi River Valley bluffs (Hardeman, 1966).

On the bluffs and on Crowley's Ridge (Fig. 1) the Lafayette Formation locally overlies the Jackson Formation (Potter, 1955; Autin et al., 1991). Lafayette Formation fluvial sands and gravels vary in thickness because both the upper and lower contacts are erosional; an average thickness is $16 \mathrm{~m}$. Overlying the Lafayette Formation on the Mississippi Valley bluffs is Pleistocene loess (Rutledge et al., 1996; Rodbell et al., 1997). This loess consists of at least three wind-blown silt units with a cumulative thickness as much as 34 m immediately east of the Mississippi River that thins eastward. An average thickness for the loess along the bluff line is $17 \mathrm{~m}$.

\section{Post-Paleozoic Structure of the NME}

Seismic reflection surveys provide information as to the timing, style, and magnitude of post-Paleozoic fault movement within the NME (Zoback, 1979; Hamilton and Zoback, 1982; Shedlock and Harding, 1982; Howe, 1985; Sexton and
Jones, 1986; 1988; Nelson and Zhang, 1991; Crone, 1992; Schweig et al., 1992; Sexton et al., 1992; Luzietti et al., 1995; Stephenson et al., 1995; Williams et al., 1995; Woolery et al., 1996; Odum et al., 1998; Van Arsdale et al., 1998; Purser and Van Arsdale, 1998). A seismic-reflection study of Crowley's Ridge and vicinity near Jonesboro (Fig. 1) imaged a west-bounding fault of the Reelfoot rift (Van Arsdale et al., 1995). On this seismic line there is no indication of Cretaceous faulting; however, the Midway Group thickens across the fault and thus indicates Paleocene normal fault displacement. This same fault and other faults that bound Crowley's Ridge also have minor Paleocene-Eocene normal displacement as revealed by thickening of the Wilcox Group. Minor post-Wilcox normal faulting, and post-Claiborne reverse faulting are evident on many of the Crowley's Ridge reflection lines. The Crittenden County fault (Luzietti et al., 1995) in eastern Arkansas and the Cottonwood Grove fault (Hamilton and Zoback, 1982; Stephenson et al., 1995) in northwestern Tennessee show middle to late Eocene Claiborne compressional deformation. The Reelfoot fault is a southwest-dipping reverse fault along the eastern margin of the Lake County uplift. This fault has been reactivated a 

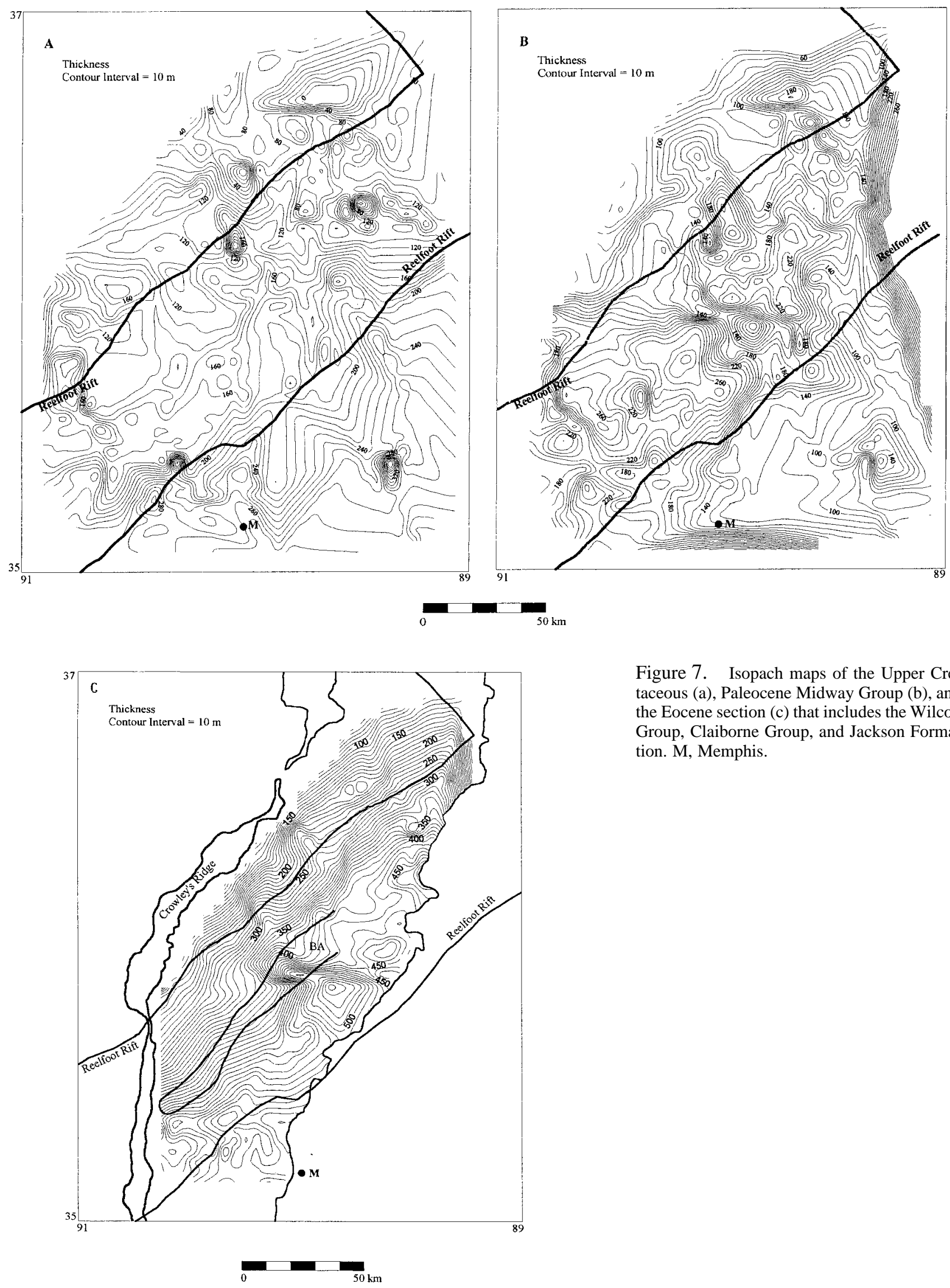

Figure 7. Isopach maps of the Upper Cretaceous (a), Paleocene Midway Group (b), and the Eocene section (c) that includes the Wilcox Group, Claiborne Group, and Jackson Formation. M, Memphis. 
number of times since the Paleozoic (Sexton and Jones, 1986; Van Arsdale et al., 1998). Bedrock exposures in the Benton Hills of southeastern Missouri reveal strike-slip faulting (Harrison and Schultz, 1994) that has been episodic throughout the Cenozoic with from 4 to 6 faulting events within the Quaternary (Harrison et al., 1997).

To better understand the post-Paleozoic structure of the NME in a regional perspective, structure-contour maps were constructed of the tops of the Paleozoic section, Late Cretaceous section, Paleocene Midway Group, and Eocene section. Similarly, isopach maps were made of the Late Cretaceous section, Midway Group, and Eocene section to determine when the deformation occurred and also to illustrate the thicknesses and distributions of these units. We shall ignore the isolated anomalies associated with individual wells and focus on the regional features of the maps.

\section{Structure Contour Maps}

Structure-contour maps illustrate that the NME is a southwest-plunging trough (Fig. 3) (Wheeler et al., 1994). However, this trough is very gentle. Specifically, the eastern limb of the NME trough dips $0.3^{\circ}$ west, the western limb dips $0.5^{\circ}$ southeast, and the trough plunges $0.1^{\circ}$ south. The Paleozoic-Late Cretaceous unconformity and overlying sediments within the NME are essentially flat lying.

The Paleozoic and Cretaceous structure-contour maps are nearly identical (Figs. 3 and 4). The Midway structurecontour map is very similar to the underlying surfaces; differences probably are because fewer seismic reflection data are available for the Midway map (Fig. 5). East-west crosssections (not shown here) across the southern map area at Memphis and across the northern map area at the Lake County uplift reveal that total structural relief on the Paleozoic, Late Cretaceous, and Midway Group is approximately $540 \mathrm{~m}, 570 \mathrm{~m}$, and $400 \mathrm{~m}$, respectively. The Figures 3-5 structure-contour maps do, however, reveal a subtle, $50-\mathrm{km}-$ wide "trench" within the NME trough. On the Paleozoic surface, the maximum depth of the trench is approximately $100 \mathrm{~m}$ both at Memphis and at the southern margin of the Lake County uplift (Fig. 3). On both the Cretaceous and Midway Group surfaces, the maximum depth of the trench is approximately $50 \mathrm{~m}$ both at Memphis and at the southern margin of the Lake County uplift (Figs. 4 and 5).

Except for the Reelfoot fault associated with the Lake County uplift, subsurface faults within the NME (Zoback, 1979; Hamilton and Zoback, 1982; Sexton and Jones, 1986; Purser and Van Arsdale, 1998; Van Arsdale, 1998; Van Arsdale et al., 1995; 1998) are not evident on our structurecontour maps. This is probably because most NME faults have too little vertical displacement to be evident in maps of this scale. However, there are a number of flexures in the contour lines that may represent northwest-trending faults (Figs. 3 and 4). It is also possible that the borders of the trench are fault-controlled. Most notable are the closely spaced contour lines near Memphis that may reflect a down- to-the-west fault (Fig. 3) (Johnson et al., 1994; Mihills, 1998).

\section{Isopach Maps}

Isopach maps of the Upper Cretaceous section, the Midway Group, and the Eocene section illustrate the thicknesses of these units within the NME (Fig. 7). The Upper Cretaceous section thickens southeasterly (Stearns, 1957). Near Memphis the Upper Cretaceous section is thick within the trench mapped on the surface of the Paleozoic; however, farther north the contours indicate that the section thickens to the southeast, nearly at right angles to the trench.

The Midway Group is thickest in the central part of the map within the boundaries of the Reelfoot rift. There is no indication of Midway thickening over the trench mapped at the top of the Late Cretaceous section.

The Eocene section isopach only includes the area between Crowley's Ridge and the bluffs, and thus only covers the central part of the other isopach maps. However, it is apparent that the Eocene section thickens from west to east. The thickest part of the Eocene section overlies the trench on the surface of the underlying Midway Group.

\section{Discussion and Conclusions}

The structure-contour map of the top of the Paleozoic displays a southerly plunging trough within the NME (Fig. 3 ). Unlike the vertically exaggerated bowl-shaped trough that is commonly portrayed, the NME unconformity and overlying Upper Cretaceous and Cenozoic sediments are nearly flat. Subtle features within the structure-contour and isopach maps do, however, reveal information on the history and tectonics of the NME.

The Upper Cretaceous isopach portrays the strata uniformly thickening to the southeast across the Reelfoot rift boundaries, and thus there is no indication that the Reelfoot rift influenced Late Cretaceous sedimentation (Fig. 7a). The Paleocene Midway Group is thicker within the boundaries of the Reelfoot rift; and, therefore, minor rift reactivation appears to have occurred during Paleocene time (Fig. 7b). The Eocene isopach does not cover the entire Reelfoot rift; however, the western rift margin does not appear to have affected Eocene deposition (Fig. 7c). Thus, we conclude that within the NME of this $2^{\circ}$ study area, the seismic-reflection studies and our maps indicate (1) no Late Cretaceous vertical faulting, (2) extensional faulting occurred during the Paleocene and lower Eocene, (3) extensional and compressional faulting occurred from middle to late Eocene, and (4) compressional faulting has and continues to occur during the Quaternary. Because the NME has apparently been subaerially exposed since deposition of the Eocene-Oligocene Jackson Formation, it is possible that the NME has been under compression since Jackson Formation time.

The structure-contour maps reveal a subtle depression that we have called a trench at the tops of the Paleozoic, Upper Cretaceous, and Midway Group along the axis of the 

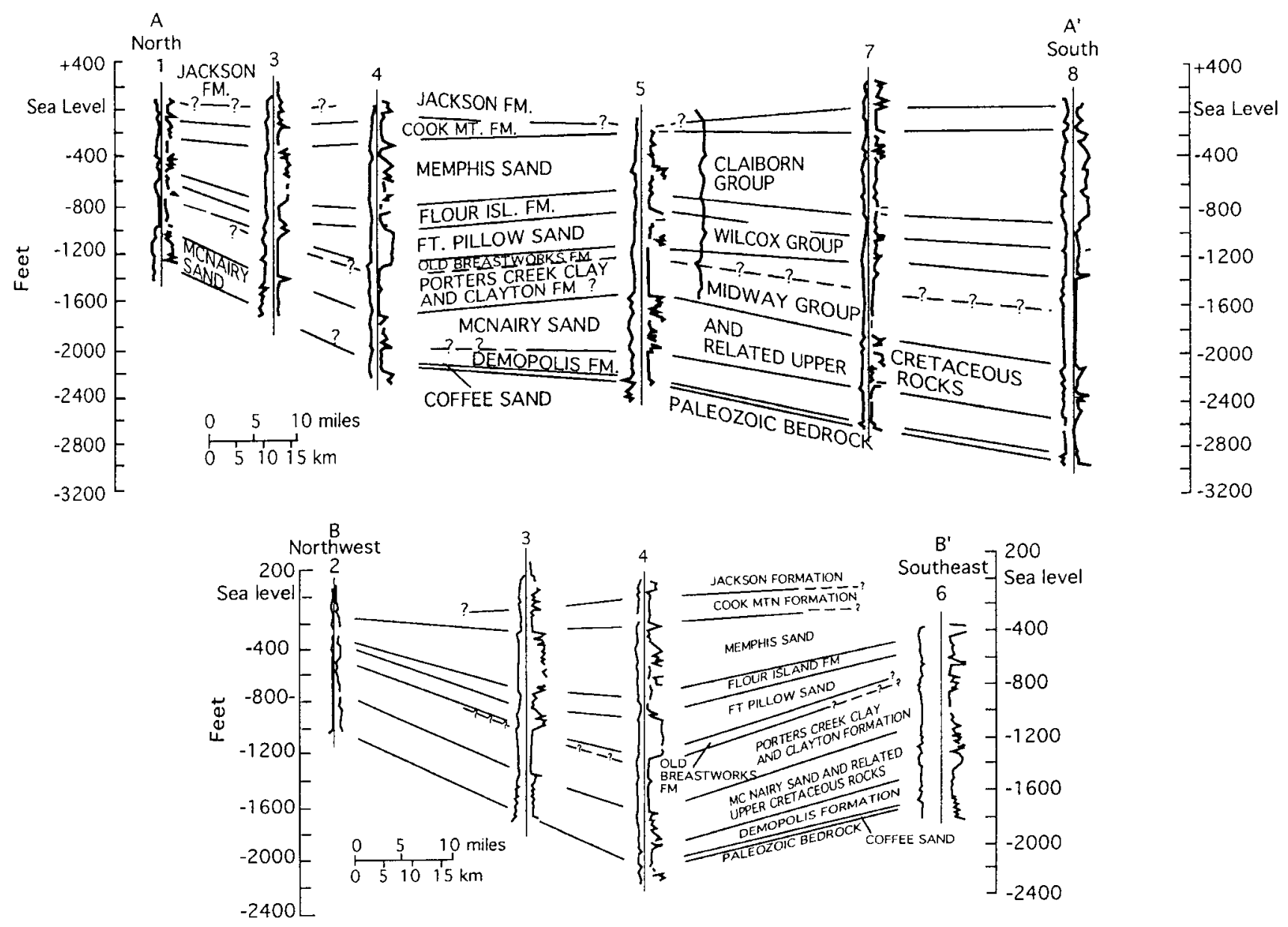

Figure 8. Stratigraphic cross-sections $A-A^{\prime}$ and $B-B^{\prime}$ in the northern Mississippi embayment. The cross-sections are located on Figure 1. The well names are 1, \#1 E. Phillips; 2, \#1 Oliver; 3, New Madrid test well 1-X; 4, \#1 J. E. Vaughn; 5, \#1T. A. Lee; 6, \#1 Vance Holt; 7, Fort Pillow test well; and 8, USGS SH:TL8 (from Crone, 1981).

NME. This trench has very similar size, depth, and location on all three surfaces. Because each of these surfaces is an unconformity, it is possible that these trenches are ancestral courses of the Mississippi River. However, we believe that the geometric similarity and superposition of the three trenches suggests a common structural origin. There is no evidence for the trench in the Upper Cretaceous or Midway Group isopachs, suggesting that the trench is younger than Paleocene. The Eocene section thickens easterly and is thickest atop the western side of the underlying trench. Thus, it appears that the trench that defines the axis of the NME formed in Eocene time. It also appears that the trench is unrelated to the Reelfoot rift because the trench crosses the southeastern border of the rift (Figs. 3-5).

The Blytheville arch/Lake County uplift is coincident with the western side of the trench for much of its length (Fig. 3). Relative uplift of the Blytheville arch/Lake County uplift appears to have formed the western margin of the trench in Eocene time. On the basis of distribution of Quaternary Mississippi River sediments, we believe this relative uplift has also occurred during the Quaternary. Mississippi River terraces descend topographically and are younger eastward from Crowley's Ridge (Saucier, 1994). Thus, the Mississippi River has shifted eastward during the Quaternary to its present Holocene position (Van Arsdale et al., 1995), atop the western half of the trench. The New Madrid seismic zone is coincident with the Blytheville arch/Lake County uplift, therefore, displacement across the western margin of the trench, albeit minor, may be localizing earthquakes of the New Madrid seismic zone and controlling the Holocene position of the Mississippi River.

Apparently contradicting the observation that a trench may be subsiding beneath the NME during Quaternary time, are both the post-Jackson Formation subaerial emergence history and the fact that the Quaternary Mississippi River alluvium is incised through the Lafayette Formation into the Eocene section. The Mississippi River in the NME has incised approximately $80 \mathrm{~m}$ since deposition of the PliocenePleistocene Lafayette Formation.

In order to reconcile this apparent contradiction, we pro- 
pose that the entire NME is under compression and undergoing differential uplift. We also believe that the NME has been rising during the Quaternary (Fisk, 1944), but the trench has lagged behind. This regional differential uplift interpretation is consistent with the observation that Crowley's Ridge appears to have Wisconsin uplift (Van Arsdale et al., 1995) and that Holocene uplift is occurring on the Blytheville arch/Lake County uplift of the New Madrid seismic zone (Hamilton and Zoback, 1982; Van Arsdale, 1998).

The post-Paleozoic NME sedimentary package increases from 477-m thick at New Madrid to $987 \mathrm{~m}$ at Shelby County. These sediments are both terrestrial and marine but their compositions are quite uniform, and there appears to be little lithification. Thus, we expect that the seismic velocities within and among these mapped units are very similar throughout the NME as is indicated by the interval velocities used in this article. Lithologic descriptions of the New Madrid and Fort Pillow test wells along the line of section from New Madrid, Missouri, to Shelby County, Tennessee, describe sands, silts, and clays. These lithologic logs do not identify any cementation and thus suggest unconsolidated clastic sediment. However, Jackson Formation siltstones are exposed in the Mississippi River bluffs of western Tennessee. These siltstones are locally quite indurated, and so we include these field observations to acknowledge that we do not really know the degree of lithification within the Late Cretaceous and Tertiary section of the NME. As in the uncertainty about lithification, we must add the caveat that seismic reflection profiles in the NME reveal acoustical impedance (strong reflections) at the unconformity surfaces at the tops of the Paleozoic, Upper Cretaceous, Midway Group, Wilcox Formation, and Eocene section (Hamilton and Zoback, 1982; Luzietti et al., 1995; Odum et al., 1995; Van Arsdale et al., 1995, 1998) that may influence seismic-wave transmission.

\section{Acknowledgments}

Research supported by the Mid America Earthquake Center under award number SG-4. We wish to thank Richard Dart, Jodi Purser, James Dorman, Yong Li, Gerard Gonthier, Kevin Cole, Devlin Fung, Randel Cox, and Bill Thomas. We also want to thank CGG Petrosystems for the use of their 3-D modeling software, Petrocaem. CERI contribution number 370.

\section{References}

Autin, W. J., S. F. Burns, B. J. Miller, R. T. Saucier, and J. I. Snead (1991). Quaternary geology of the Lower Mississippi Valley, in Quaternary Nonglacial Geology: Conterminous U.S., R. B. Morrison (Editor), GSA, Boulder, Colorado, 547-582.

Boswell, E. H., G. K. Moore, L. M. MacCary, and others (1965). Cretaceous aquifers in the Mississippi Embayment, U.S. Geol. Surv. Profess. Pap. 448-C, 37.

Brahana, J. V., and T. O. Mesko (1988). Hydrogeological and preliminary assessment of regional flow in the upper Cretaceous and adjacent aquifers in the northern Mississippi embayment, U.S. Geol. Surv. Water Res. Invest. Rept. 87-4000, 65.

Braile, L. W., G. R. Keller, W. J. Hinze, and E. G. Lidiak (1982). An ancient rift complex and its relation to contemporary seismicity in the New Madrid seismic zone, Tectonics 1, 225-237.

Burke, K. and J. F. Dewey (1973). Plume-generated triple junctions: key indicators in applying plate tectonics to old rocks, J. Geol. 81, 406433.

Caplan, W. M. (1954). Subsurface geology and related oil and gas possibilities of northeastern Arkansas, Ark. Res. and Development Com. Div. of Geol. Bull. 20, 124.

Cox, R. T., and R. B. Van Arsdale (1997). Hotspot origin of the Mississippi embayment and its possible impact on contemporary seismicity, Eng. Geol. 46, 5-12.

Crone, A. J. (1981). Sample description and stratigraphic correlation of the New Madrid test well-1-X, New Madrid County, Missouri, U.S. Geol. Surv. Open-File Rept. 81-426, 26.

Crone, A. J. (1992). Structural relations and earthquake hazards of the Crittenden County fault zone, northeastern Arkansas, Seism. Res. Lett. 63, 249-262.

Ervin, C. P. and L. D. McGinnis (1975). Reelfoot rift-reactivated precursor to the Mississippi Embayment, Geol. Soc. Am. Bull. 86, 1287-1295.

Fisk, H. N. (1944). Geological investigation of the alluvial valley of the lower Mississippi River, U.S. Army Corps of Engineers, Mississippi River Comm., Vicksburg, Mississippi, 78.

Frederiksen, N. O., L. M. Bybell, R. A. Christopher, A. J. Crone, L. E. Edwards, T. G. Gibson, J. E. Hazel, J. E. Repetski, D. P. Russ, C. C. Smith, and L. W. Ward (1982). Biostratigraphy and paleoecology of Lower Paleozoic, Upper Cretaceous, and Lower Tertiary rocks in U.S. Geological Survey New Madrid test wells, southeastern Missouri, $T u$ lane Studies in Geology and Paleontology 17, 23-45.

Galloway, W. E., D. G. Bedout, W. L. Fisher, J. B. Dunlap, R. CabreraCastro, J. E. Lugo-Rivera, and T. M. Scott (1991). The Geology of North America, Vol. J, The Gulf of Mexico Basin, Geological Society of America, Boulder, Colorado, 245-324.

Hamilton, R. M. and M. D. Zoback (1982). Tectonic features of the New Madrid seismic zone from seismic-reflection profiles, in Investigations of the New Madrid, Missouri, Earthquake Region, F. A. McKeown and L. C. Pakiser (Editors), U.S. Geol. Surv. Profess. Pap. 1236, 55-82.

Hardeman, W. D. (1966). Geologic map of Tennessee west sheet, State of Tenn. Dept. of Conserv. Div. of Geol., scale 1:250,000.

Harrison, R. W., J. R. Palmer, D. Hoffman, J. D. Vaughn, S. L. Forman, J. McGeehin, and N. O. Frederiksen (1997). Profiles and documentation of fault-exploration trenches in the English Hill area, Scott City 7.5minute quadrangle, Missouri, U.S. Geol. Surv. Open-File Rept. $97-$ 474, 96.

Harrison, R. W., and A. Schultz (1994). Strike-slip faulting at Thebes Gap, Missouri and Illinois: implications for New Madrid tectonism, Tectonics 13, 246-257.

Hosman, R. L. (1996). Regional stratigraphy and subsurface geology of Cenozoic deposits, Gulf Coastal Plain, south-central United States, U.S. Geol. Surv. Profess. Pap. 1416-G, 35.

Howe, J. R. (1985). Tectonics, sedimentation, and hydrocarbon potential of the Reelfoot aulacogen, Master's Thesis, University of Oklahoma, Norman, Oklahoma, 109.

Johnson, P. R., I. Zietz, and W. A. Thomas (1994). Possible Neoproterozoic-early Paleozoic grabens in Mississippi, Alabama and Tennessee, Geology 22, 11-14.

Kane, M. F., T. G. Hildenbrand, and J. D. Hendricks (1981). Model for the tectonic evolution of the Mississippi embayment and its contemporary seismicity, Geology 9, 563-568.

Keckler, D. (1995). Surfer for Windows, Version 6 User's Guide, 2nd ed., Golden Software, Inc., Golden, Colorado.

Luzietti, E. A., L. R. Kanter, K. M. Shedlock, E. S. Schweig, and R. B. Van Arsdale (1995). Shallow deformation along the Crittenden County fault zone near the southeastern margin of the Reelfoot rift, northeast Arkansas, in Investigations of the Nw Madrid seismic zone, K. M. Shedlock and A. C. Johnston (Editors), U.S. Geol. Surv. Profess. Pap. 1538-J, 23. 
Marcher, M. V., and R. G. Stearns (1962). Tuscaloosa Formation in Tennessee, Geol. Soc. Am. Bull. 73, 1365-1386.

Mihills, R. K. (1998). A structural analysis of the New Madrid seismic zone from structure contour maps and a three-dimensional model, Master's Thesis, University of Memphis, Memphis, Tennessee, 82.

Moore, G. K., and D. L. Brown (1969). Stratigraphy of the Fort Pillow test well, Lauderdale County, Tennessee, Tenn. Dept. of Conserv., Div. of Geol., Report of Investigations 26.

Murray, G. E. (1961). Geology of the Atlantic and Gulf Coastal Province of North America, Harper \& Brothers, New York, 692.

Nelson, J. W. (1998). Bedrock geology of the Paducah $1^{\circ} \times 2^{\circ}$ CUSMAP quadrangle, Illinois, Indiana, Kentucky, and Missouri, U.S. Geol. Surv. Bull. 2150-B, 36.

Nelson, K. D., and J. Zhang (1991). A COCORP deep reflection profile across the buried Reelfoot rift, south-central United States, Tectonophysics 197, 271-293.

Odum, J. K., E. A. Luzietti, W. J. Stephenson, K. M. Shedlock, and J. A. Michael (1995). High-resolution, shallow, seismic reflection surveys of the northwest Reelfoot rift boundary near Marston, Missouri, U.S. Geol. Surv. Profess. Pap. 1538-P, 18.

Odum, J. K., W. J. Stephenson, K. M. Shedlock, and T. L. Pratt (1998). Near surface structural model for deformation associated with the February 7, 1812, New Madrid, Missouri, earthquake, Geol. Soc. Am. Bull. 46, 149-162.

Olive, W. W. (1980). Geologic maps of the Jackson Purchase region, Kentucky, U.S. Geol. Surv. Misc. Invest. Series, scale 1:250,000.

Petersen, J. C., M. E. Broom, and W. V. Bush (1985). Geohydrologic units of the Gulf Coastal Plain in Arkansas, U.S. Geol. Surv. WaterResources Inves. Rept. 85-4116, 20.

Potter, P. E. (1955). The petrology and origin of the Lafayette gravel, $J$. Geol. 63(1), 1-38, 115-132.

Pryor, W. A. (1960). Cretaceous sedimentation in upper Mississippi embayment, Am. Assoc. Pet. Geol. Bull. 44, 1473-1504.

Purser, J. L., and R. B. Van Arsdale (1998). Structure of the Lake County uplift: New Madrid seismic zone, Seism. Soc. Am. Bull. 88, 12041211.

Rodbell, D. T., S. L. Forman, J. Pierson, and W. C. Lynn (1997). Stratigraphy and chronology of Mississippi Valley loess in western Tennessee, Geol. Soc. Am. Bull. 109, 1134-1148.

Russell, E. E., D. M. Keady, E. A. Mancini, and C. E. Smith (1982). Upper Cretaceous in the lower Mississippi embayment of Tennessee and Mississippi: lithostratigraphy and biostratigraphy, Field trip guidebook for the 1982 annual meeting of the Geol. Soc. Am., New Orleans, Louisiana, 40.

Rutledge, E. M., M. J. Guccione, H. W. Markewich, D. A. Wysocki, and L. B. Ward (1996). Loess stratigraphy of the lower Mississippi valley, Eng. Geol. 45, 167-183.

Saucier, R. T. (1994). Geomorphology and Quaternary geologic history of the lower Mississippi Valley, U.S. Army Corps of Engineers Waterways Experiment Station, 364.

Schweig, E. S., Shen Fan, L. R. Kanter, E. A. Luzietti, R. B. Van Arsdale, K. M. Shedlock, and K. W. King (1992). Shallow seismic reflection survey of the Bootheel lineament area, southeastern Missouri, Seism. Res. Lett. 63, 285-295.

Sexton, J. L., H. Henson, P. Dial, and K. Shedlock (1992). Mini-Sosie high resolution seismic reflection profiles along the Bootheel Lineament in the New Madrid seismic zone, Seism. Res. Lett. 63, 297-307.

Sexton, J. L., and P. B. Jones (1986). Evidence for recurrent faulting in the New Madrid seismic zone from Mini-Sosie high-resolution reflection data, Geophysics 51, 1760-1788.
Sexton, J. L., and P. B. Jones (1988). Mini-Sosie high-resolution reflection survey of the Cottonwood Grove fault in northwestern Tennessee, Seism. Soc. Am. Bull. 78, 838-854.

Sharp, J. M., C. W. Kreitler, and J. Lesser (1991). The Geology of North America Vol. J, The Gulf of Mexico Basin, The Geological Soc. of America 529-543.

Shedlock, K. M., and S. T. Harding (1982). Mississippi River seismic survey, Geophy. Res. Lett. 9, 1275-1278.

Sohl, N. F., E. R. Martinez, P. Salmeron-Urena, and F. Soto-Jaramillo (1991). The Geology of North America Vol. J, The Gulf of Mexico Basin, Geological Society of America, Boulder, Colorado, 205-244.

Stearns, R. G. (1957). Cretaceous, Paleocene, and Lower Eocene geologic history of the northern Mississippi embayment, Geol. Soc. Am. Bull. 68, 1077-1100.

Stearns, R. G., and M. V. Marcher (1962). Late Cretaceous and subsequent structural development of the northern Mississippi embayment area, Geol. Soc. Am. Bull. 73, 1387-1394.

Stephenson, W. J., K. M. Shedlock, and J. K. Odum (1995). Characterization of the Cottonwood Grove and Ridgely faults near Reelfoot Lake, Tennessee, from high-resolution seismic reflection data, U.S. Geol. Surv. Profess. Pap. 1538-1, 1-10.

Van Arsdale, R. B. (1998). Seismic hazards of the upper Mississippi embayment, U.S. Army Corps of Engineers Waterways Experiment Station Contract Report GL-98-1, 55.

Van Arsdale, R. B., J. Purser, W. Stephenson, and J. Odum (1998). Faulting along the southern margin of Reelfoot Lake, Tennessee, Seism. Soc. Am. Bull. 88, 131-139.

Van Arsdale, R. B., R. A. Williams, E. S. Schweig, E. S. Shedlock, J. K. Odum, and K. W. King (1995). The origin of Crowley's Ridge, northeastern Arkansas: erosional remnant or tectonic uplift?, Seism. Soc. Am. Bull. 85, 963-985.

Wheeler, R. L., S. Rhea, and R. L. Dart (1994). Map showing structure of the Mississippi Valley graben in the vicinity of New Madrid, Missouri, USGS Miscellaneous Field Studies Map MF-2264-D, scale $1: 250,000$.

Williams, R. A., E. A. Luzietti, and D. L. Carver (1995). High-resolution seismic imaging of Quaternary faulting on the Crittenden County fault zone, New Madrid seismic zone, northeastern Arkansas, Seism. Res. Lett. 66, 42-57.

Woolery, E. W., Z. Wang, R. L. Street, and J. B. Harris (1996). A P-and SH-wave seismic reflection investigation of the Kentucky Bend scarp in the New Madrid seismic zone, Seism. Res. Lett. 67, 67-74.

Zoback, M. D. (1979). Recurrent faulting in the vicinity of Reelfoot Lake, northwestern Tennessee, Geol. Soc. Am. Bull. Part 1, 90, 1019-1024.

Department of Geological Sciences

402 J.M. Smith Building

University of Memphis

Memphis, Tennessee 38152

(R.B.V.)

Department of Geological Sciences

MS 172

University of Nevada

MacKay School of Mines

Reno, Nevada 89557-0138

(R.K.T.) 